\title{
Launch Vehicle Performance Using Metallized Propellants
}

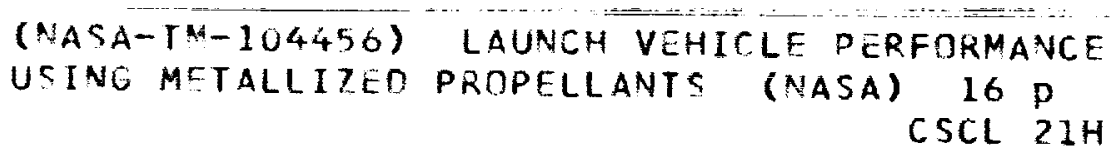

Unclas

$63 / 20 \quad 0019775$

Bryan Palaszewski

Lewis Research Center

Cleveland, Ohio

and

Richard Powell

Langley Research Center

Hampton, Virginia

Prepared for the

27th Joint Propulsion Conference

cosponsored by the AIAA, SAE, ASME, and ASEE

Sacramento, California, June 24-27, 1991 


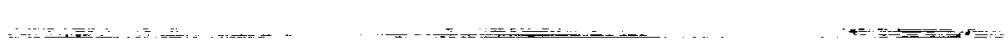


LAUNCH VEHICLE PERFORMANCE USING METALLIZED PROPELLANTS

\author{
Bryan Palaszewski*,* \\ National Aeronautics and Space Administration \\ Lewis Research Center \\ Cleveland, $\mathrm{OH}$ \\ and \\ Richard Powel1** \\ National Aeronautics and Space Administration \\ Langley Research Center \\ Hampton, VA
}

\begin{abstract}
Metallized propellant propulsion systems are considered as replacements for the solid rocket boosters and liquid sustainer stages on the current launch vehicles: both the space Transportation system (STS) and the Titan IV. Liquid Rocket Boosters for the STS were analyzed as replacements for the current solid Rocket Boosters. These boosters can provide a liquid propulsion system within the volume constraints of a solid Rocket Booster. A replacement for the Space Shuttle Main Engines using metallized $\mathrm{O}_{2} / \mathrm{H}_{2} / \mathrm{Al}$ was studied. The liquid stages of the Titan IV were also investigated; the $A-$ 50 fuel was replaced with metallized storable A-50/Al.

A metallized propellant is similar to a traditional liquid propellant. However, it has metal particles, such as aluminum, that are suspended in a gelled fuel, such as hydrogen, RP-1, Aerozine-50 (A-50) or monomethyl hydrazine (MMH). The fuels then undergo combustion with liquid oxygen or nitrogen tetroxide (NTO).

These propellants provide options for increasing the performance of existing launch vehicle chemical propulsion systems by increasing fuel density or specific impulse $\left(I_{\mathrm{sp}}\right)$, or both. These increases in density and $I_{\mathrm{sp}}$ can significantly reduce the propulsion system liftoff weight and allow a liquid rocket booster to fit into the same volume as an existing solid rocket booster. Also, because gelled fuels are akin to liquid propellants, metallized systems can provide enhanced controllability over solid propulsion systems. Gelling of the propellant also reduces the sensitivity to impacts and consequently reduces the propellant explosion hazard.
\end{abstract}

\section{Nomenclature}

ALS Advanced Launch System

Al Aluminum

\begin{tabular}{|c|c|}
\hline$A-50$ & Aerozine-50 \\
\hline ET & External Tank \\
\hline GLOW & Gross Lift off Weight \\
\hline $\mathrm{H}_{2}$ & Hydrogen \\
\hline$I_{\mathbf{s p}}$ & Specific Impulse $\left(1 b_{\mathrm{f}}-s / 1 b_{\mathrm{m}}\right)$ \\
\hline LRB & Liquid Rocket Booster \\
\hline MECO & Main Engine Cut off \\
\hline ML & Metal Loading \\
\hline MPS & Main Propulsion Subsystem \\
\hline NTO & Nitrogen Tetroxide \\
\hline MMH & Monomethyl Hydrazine \\
\hline NLS & National Launch system \\
\hline $\mathrm{O}_{2}$ & oxygen \\
\hline OMS & Orbital Maneuvering Subsystem \\
\hline RP-1 & Rocket Propellant-1 \\
\hline SRB & Solid Rocket Booster \\
\hline SRM & Solid Rocket Motor \\
\hline SSME & Space Shuttle MaIn Englnes \\
\hline STS & Space Transportation system \\
\hline STS-C & Space Transportation System-Cargo \\
\hline VAB & Vehicle Assembly Building \\
\hline$\Delta \mathrm{V}$ & Velocity Change (m/s) \\
\hline
\end{tabular}

\section{Introduction}

Future launch vehicles will deliver increasingly larger and more massive payloads to orbit. Existing launch vehicles

\footnotetext{
* Program Manager, Metaliized Propellant Program

* * AIAA Member
}

Copyright $\odot 1991$ by the American Institute of Aeronautics and Astronautics, Inc. No copyright is asserted in the United States under Title 17, U.S. Code. The U.S. Govern ment has a royalty-free license to exercise all rights under the copyright claimed herein for Governmental purposes. All other rights are reserved by the copyright owner. 
will require continuing upgrades in performance to accommodate the increasing payload needs of NASA missions. Commercial launch vehicle manufacturers are looking to increase the payload capability of their future designs (Refs. 1 and 2). The NASA and Air Force plans for the National Launch System (NLS), the Advanced Launch system (ALS) and the space Transportation systemCargo (STS-C) demand payloads to orbit equal to or exceeding $68,000 \mathrm{~kg}$. (Refs. 3 and 4 ). These payloads would be required for large piloted lunar base flights and Mars exploration missions (Ref. 5) as well as for some aspects of the proposed strategic Defense Initiative operations (Ref. 6).

As payload masses increase, the propellant needed for the launch vehicle also rises. The larger propellant loads lead to larger and larger stage lengths and volumes. To deliver higher payload masses to orbit, higher performance and higher $I_{\mathrm{sp}}$ rocket engines will be required. Also, to maintain these vehicles' dimensions within reasonable sizes and to reduce the volume of the vehicle's stages, higher density propellants will be destrable.

The propulsion technologies that are available to meet these performance and/or volume demands are many and varied: liquid, solid and hybrid propulsion are the primary alternatives for launch vehicles. For example, the Advanced Solid Rocket Motor (ASRM) is under consideration for enhancing the STS (Ref. 7). Solids and hybrids are two of the technologies for increasing propellant density. Their delivered specific impulse is typicaliy not as high as a liquid propulsion alternative. With advanced liquid propulsion, many different types of propellants can be developed to increase performance.

Potentially, one of the most-attractive liquid propellant options is metallized propellants. Metallized propellants can deliver high $I_{\mathrm{sp}}$ or high fuel density, or both. In the succeeding sections some of the design features and attributes of metallized propellants will be discussed and analyzed.

Liquid Rocket Boosters (LRB) for the STS were analyzed as replacements for the current Solid Rocket Boosters (SRB). A replacement for the space shuttle Main Engines using metallized $\mathrm{O}_{2} / \mathrm{H}_{2} / \mathrm{Al}$ was also studied. The liquid stages of the Titan IV were also investigated; the $A-50$ fuel was replaced with metallized storable A-50/A1.

\section{Summary of Results}

With the sTs Liquid Rocket Boosters, metallized $\mathrm{O}_{2} / \mathrm{RP}-1 / \mathrm{Al}$ and NTO/MMH/Al are able to provide an LRB that is shorter than the existing SRB. Even when including the potential losses caused by two-phase flow losses in engine analysis, the metallized LRB is able to deliver the baseline STS payload of $22,527 \mathrm{~kg}\left(49,664\left(1 b_{\mathrm{m}}\right)\right.$. If the two-phase flow losses are minimized, the STS payload may be increased to $25,674 \mathrm{~kg}$
$(56,600 \mathrm{~kg})$ with $\mathrm{O}_{2} / \mathrm{RP}-1 / \mathrm{Al}$. A payload of $30,482 \mathrm{~kg}(67,200 \mathrm{lb})$ is projected using a metallized NTO/MMH/Al LRB. The volume of an $\mathrm{LRB}$ or an External Tank using $\mathrm{O}_{2} / \mathrm{H}_{2} / \mathrm{Al}$ were much larger than the existing SRB and External Tank volume. The Titan IV payload (with no upper stage) was increased by 11.2 to 11.6 percent over the existing design. This Titan used NTO/A-50/Al propellants only in the core vehicle.

\section{Background}

\section{Why Metallized Propellants?}

One advanced propulsion option that can provide benefits for Earth to orbit vehicles uses metallized propellants. These propellants offer increases in the overall propellant density and/or the $I_{s p}$ of $a$ propulsion system. These increases can enable significant launch mass reductions or payload increases over conventional chemical propellants. Metallized propellants are propellants with metal added to the fuel or the oxidizer. Typically, the metal is in the form of micron-sized particles. They are suspended in a gelled propellant to increase its combustion energy or its density, or both. The $I_{s p}$ of an engine is proportional to:

$$
I_{s p} \propto(T / M W)^{1 / 2}
$$

where:

$\mathbf{T}$

MW

\section{Combustion Temperature}

Molecular Weight of Combustion Products

A combination of increased combustion temperature, or reductions in the molecular weight of the exhaust products, or both, increases the $I_{\text {sp }}$ of the propulsion system. Increased $I_{\mathrm{sp}}$ reduces the propellant required for a given mission. The increases in propellant density also reduce the tankage volume and mass. Because many of the propulsion system elements are dependent on the propellant mass and volume, increasing the propellant density decreases component and tankage weights, thus allowing large reductions in the overall dry mass.

To increase the payload capability of existing launch vehicles and their upper stages, higher $I_{\mathrm{sp}}$ systems or higher density propeliants, or both, will be needed. Previous studies of Mars and lunar missions (Refs. 8, 9 and 10), the STS LRBS (Ref. II and 12 ) and STS and STS-C upper stages (Ref. 13) have determined that metallized propellants are an attractive alternative to traditional propellants for future space transportation systems.

\section{Liquid Rocket Boosters}

Two studies have been conducted to determine the benefits of LRBs (Refs. 11 and 12) over the current SRB for the space Transportation system (STS). There are several important features of an LRB. These include added 
payload to orbit, thrust controllability, launch vehicle in-flight safety and launch operations safety.

In the LRB studies, a payload of up to $31,979 \mathrm{~kg}\left(70,5001 \mathrm{~b}_{\mathrm{m}}\right)$ was desired. This is a sizable bolstering of the STS over the current capability of 22,680 to $24,948 \mathrm{~kg}$ $\left(50,000\right.$ to $55,0001 b_{m}$, Ref. 15). Such a payload gain can be a great benefit for future space station flights and future exploration mission support. The LRB can also provide a controllable and variable thrust level. This control increases mission flexibility. During the ascent to orbit, the ability to control the thrust level of a booster stage is important for safety. If a problem were to occur with a rocket engine, the engine could be throttled down to minimize the danger to the launch vehicle and the crew. An LRB can also be commanded to terminate its firing if a problem arose during the launch; this option is not available with the SRB.

In addition to the safety of the vehicle and the flight crew during launch, the safety of the launch facilities is also critical. Currently, the segments of the solid rocket motors are assembled in the vehicle Assembly Building (VAB). This procedure introduces a potential hazard in the assembly of the STS hardware. By using an LRB, potentially hazardous fuels are taken out of the VAB and kept near the launch pad. With NTO/MMH/Al propellants, the processing at the pad may require additional consideration due to its toxicity over $\mathrm{O}_{2} / \mathrm{RP}-1 / \mathrm{Al}$ and $\mathrm{O}_{2} / \mathrm{H}_{2} / \mathrm{Al}$.

With metallized propellants, there is an added safety advantage in handling. Because the fuel is gelled, it prevents widespread spillage if it were released from the propellant tank (Ref. 14). Cleanup of the spill is easier because the spill is restricted to a more confined area. This is particularly true of storable metallized fuels. Also, the gel makes the propellants less sensitive to high-energy particles that penetrate the propellant tank (Ref. 14). If a projectile penetrates the tank (such as a wrench dropped during ground assembly, micrometeoroids, space debris, etc.), the gelled propellant will prevent a catastrophic explosion.

Both LRB studies also gave some preliminary consideration to metallized propulsion systems for the LRB. The booster designs used NTO/MMH/Al and $O_{2} / \mathrm{RP}-1 / \mathrm{Al}$. Of all of the LRB types studied, the metallized boosters were able to fit most closely within the existing Solid Rocket Booster (SRB) dimensions. This allows LRBs to be considered for the current STS with minimal changes to the existing launch facilities. strict geometric constraints are imposed by the current STS launch facilities. If the boosters have dimensions which are other than that of the current SRB, significant alterations may have to be made to many launch facilities, including the Mobile Launch Platform, the launch pad's flame trench and the access platforms on the
Rotating and the Fixed service structures of Launch Complex $39 \mathrm{~A}$ and $\mathrm{B}$. Introducing a new propulsion technology will be more-easily effected if the changes to the existing launch systems and facilities are minimal.

In this study, the STS and Titan IV launch vehicle designs were studied in how they could accommodate metallized propellants. For the STS, the SRBs were replaced with LRBs using metallized fuels: RP-1/Al, MMH/Al and $\mathrm{H}_{2} / \mathrm{Al}$. Also investigated were an External Tank (ET) and space shuttle Main Engines (SSME) that used metallized $\mathrm{H}_{2} / \mathrm{Al}$ fuel. The Titan launch vehicle was modified so that the liquid-fueled core used metallized A-50/Al.

To establish the benefits of metallized propellant for launch vehicles, the missions and propulsion system designs must be considered together and analyzed. The succeeding sections will discuss these aspects and the results of the overall systems analysis.

\section{Propulsion Systems Analyses}

In determining the potential performance advantages of metalized propellants, a series of trade studies were performed. These studies used the launch mass and/or volume constraints of a series of STS and Titan launch vehicle options to define the capability of future vehicle designs. After determining the launch vehicle constraints and formulating the missions and generic designs of their boosters and stages, these elements can be folded together to find the performance of the total vehicle for the varying mission requirements.

Iñ the analyses presented here, several figures of merit are considered. These are the payload delivery mass to an Earth orbit, the length and diameter of the vehicle and the Gross Lift off Welght (GLOW).

To compute the figures of merit, the rocket equation was used:

$$
\Delta V=I_{s p} g \text { in }\left(m_{o} / m_{f}\right)
$$

where:

$\Delta \mathrm{V}$

Velocity Change

$I_{\mathrm{sp}} \quad$ Specific Impulse

g Gravitational Acceleration

$\mathrm{m}_{0} \quad$ Initial Mass

$m_{f} \quad$ Final Mass

Two different methods of analysis were used to analyze the STS and the Titan IV. The rocket equation was used for the STS analysis and for the Titan IV, a trajectory analysis code was used. Factoring in the launch vehicle constraints, the engine performance and the launch vehicle stage mass-scaling equations, the size of the 
boosters and stages for various payloads can be calculated. In the following sections, the constraints on the launch vehicle designs are discussed.

\section{Launch Vehicle Design Constraints}

In the analyses of the STS performance, the Ulysses launch mission parameters were used as a guide (Ref. 15). The Ulysses mission is a unmanned spacecraft that will explore outside of the ecliptic plane of the Solar system. It was launched toward Jupiter with a two-stage IUS and an additional Payload Assist Module (PAM) upper stage deployed from the STS. This mission is the heaviest STS payload to date. The STS vehicle has two large SRBs flanking the combined External Tank (ET) and orbiter. The vehicle and propellant masses of the baseline STS mission are listed in Table $I$. The total payload mass delivered to orbit was 22,527 $\mathrm{kg}\left(49,6641 \mathrm{~b}_{\mathrm{m}}\right)$. This mass includes 20,873 $\mathrm{kg}(46,017 \mathrm{lb})$ of payload and $1,654 \mathrm{~kg}$ $\left(3,647 \quad 1 b_{m}\right)$ of Manager's Reserves (or payload contingency. Ref. 15). The length and diameter of the SRB are $149 \mathrm{ft}$ and 12.2 ft, respectively (Ref, 16). For the ET, the length and diameter are $153.8 \mathrm{ft}$ and 27.6 ft, respectively. To use metallized propellants, the ET design must be modified. The ET uses the oxygen tank as part of the nose section. Because of the aerodynamic shaping of the oxygen tank, the ET with metallized propellants was compared to the existing ET based on volume of the new metallized propellant tank rather than the length of the tank. The total volume of the existing ET is $2069 \mathrm{~m}^{3}\left(73,081 \mathrm{ft}^{3}\right)$.

The baseline payload to orbit for the Titan IV is $14,643 \mathrm{~kg}\left(32,2821 \mathrm{~b}_{\mathrm{m}}\right)$. The Titan is composed of two large solid rocket boosters for the initial liftoff (stage 0), a core vehicle with two booster stages (stages 1 and 2) and no additional upper stage. The core and the boosters are $3.05 \mathrm{~m}(10 \mathrm{ft})$ in diameter. The stage 1 tankage volume is $129.7 \mathrm{~m}^{3}\left(4,581.7 \mathrm{ft}^{3}\right)$ and the volume of Stage 2 is $29.4 \mathrm{~m}^{3}\left(1037.3 \mathrm{ft}^{3}\right)$. Metallized propellants were only investigated for the replacement of the core vehicle propellants.

Table I

Baseline STS Mass Summary

Subsystem Mass (kg)

\begin{tabular}{lr}
\hline Payload & $22,527.4$ \\
Orbiter & $93,762.2$ \\
External Tank & \\
With Residuals & $36,050.1$ \\
ET $\mathrm{O}_{2} / \mathrm{H}_{2}$ Propellant & $719,539.1$ \\
Two SRBs Plus Non-Propulsive & \\
Losses & $171,397.5$ \\
SRB Propellant & $1,008,892.0$ \\
Total & $2,052,168.3$ \\
\hline
\end{tabular}

\section{Propulsion System Design}

For the STS IRBS, both pump- and pressurefed boosters were analyzed. All of the remaining engine designs for the STS SSME and Titan stages' engines are pump-fed. Some of the design parameters for the engines were guided by the results of the previous LRB studies.

Engine Performance. Using a computer simulation code (Ref. 17), the engine performance of the metallized propellant combinations was estimated. The propellants were provided to the combustion chamber in the liquid state. A different $\epsilon$ was chosen for the pump- and pressure-fed engines. A fixed area was available at the base of the LRB. The chamber pressure of the pump-fed engine allowed four engines, each with a 30:1 expansion ratio nozzle to fit within the LRB base area. The engine chamber pressure was 1000 psia. For the pressure-fed boosters, the 350-psia chamber pressure allowed an $\epsilon$ of only 7:1 to fit within the area at the base of the LRB. As with the pump-fed LRB, four engines were used. These chamber pressures were selected based upon the designs of the various engines under consideration for future launch vehicles (Refs. 11 and 12). The SSME with metallized propellants had a 3000 -psia chamber pressure and $77.5: 1$ expansion ratio. These values are the design point of the SSME. With the Titan IV engines, the metallized engines used the same engine $\epsilon$ and chamber pressure as the current Titan designs: $15: 1$ and 857 psia for stage 1 and $49.2: 1$ and 860 psia for the second stage.

Table II contrasts the predicted performance of several propulsion systems with and

Table II

Non-Metallized and Metallized Engine Performance

Vehicle and
Propellant $\quad \begin{gathered}I_{s p} \\ \text { No Metal Metal }\end{gathered} \quad I_{s p}$ Efficiency

\begin{tabular}{|c|c|c|c|}
\hline $\begin{array}{l}\text { SRB: } \\
\text { SRB } \\
\mathrm{O}_{2} / \mathrm{RP}-1 \\
\mathrm{NTO} / \mathrm{MMH} \\
\mathrm{O}_{2} / \mathrm{H}_{2}\end{array}$ & $\begin{array}{r}265.5 \\
324.5 \\
307.7 \\
410.2\end{array}$ & $\begin{array}{l}\pi / a \\
317.3 \\
318.9 \\
419.0\end{array}$ & $\begin{array}{c}n / a \\
0.920 \\
0.920 \\
0.940\end{array}$ \\
\hline $\begin{array}{l}\text { Pressure-Fed: } \\
\mathrm{O}_{2} / \mathrm{RP}-1 \\
\mathrm{NTO} / \mathrm{MMH}\end{array}$ & $\begin{array}{l}289.4 \\
280.4\end{array}$ & $\begin{array}{l}284.8 \\
278.3\end{array}$ & $\begin{array}{l}0.920 \\
0.920\end{array}$ \\
\hline $\begin{array}{l}\text { Main Propulsic } \\
\mathrm{O}_{2} / \mathrm{H}_{2}\end{array}$ & $\begin{array}{c}\text { on Options } \\
452.66\end{array}$ & -460.6 & 0.974 \\
\hline $\begin{array}{l}\text { Titan IV: } \\
\text { Stage } 1 \text { optior } \\
\text { NTO } / \text { A }-50\end{array}$ & ons - & 310.2 & 0.914 \\
\hline $\begin{array}{l}\text { Stage } 2 \text { optior } \\
\text { NTO/A-50 }\end{array}$ & ans - & 330.0 & 0.906 \\
\hline
\end{tabular}

* Aluminum is added to the fuel 
without metallized fuel. The increases in $I_{s p}$ are typically several $1 b_{f}-s / 1 b_{m}$. An engine $I_{s p}$ efficiency $(\eta)$ was used to modify the codepredicted $I_{s p}$. The Table II $I_{s p}$ values have included in them the $\eta$. The $\eta$ is the ratio of the engine performance shown in Table II and the code-predicted $I_{\mathrm{sp}}$. The reduction due to $\eta$ reflects the losses from the nozzle boundary layer, engine cycle inefficiencies and other propulsion system losses. The engine efficiencies were derived using the performance estimates from liquid engine systems (References 18 through 21) and comparisons with the vacuum $I_{\text {sp }}$ predicted by the engine code. In this analysis, metallized propellants were given the same engine efficiency as the non-metallized systems. There are additional losses that have not been included in this analysis that may potentially penalize the metallized propellant cases, such as two-phase flow losses in the exhaust and the nozzle boundary layer, and nozzle erosion. Numerical modeliing, propellant rheology experiments and hot-fire engine testing have been conducted to determine the potential engine efficiency of metallized propellants (Refs. 22 through 26). The effect of lower

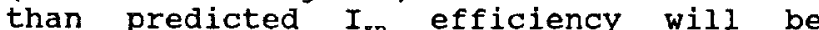
discussed later in the paper.

The mixture ratios and the metal loading for these propulsion designs are given in Table III. The metal loading represents the fraction (by mass) of aluminum in the total mass of the fuel. The mixture ratio is defined as it is for traditional chemical propulsion: the ratio of the total oxidizer mass to the total fuel mass. In selecting the "best" metallized system design, the propellant metal loading, its effects on the engine $I_{s p}$ and the propulsion system dry mass

Table III

Rocket Engine Metal Loadings and Mixture Ratios

$\begin{array}{lll}\text { Vehicle and } & \text { Metal } & \text { Mixture } \\ \text { Propellant } & \text { Loading } & \text { Ratio }\end{array}$

(8) Metal No Metal

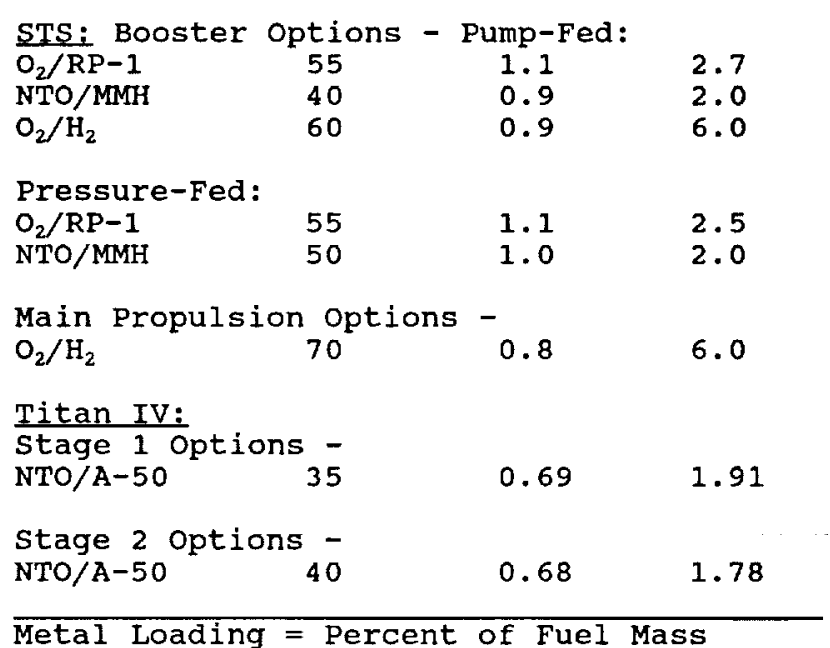

must be analyzed. Some of the issues that are important in determining the appropriate design for a metallized propulsion system are discussed below: the propellant density, the performance and the system dry mass.

A wide range of metal loadings were considered for $\mathrm{O}_{2} / \mathrm{H}_{2} / \mathrm{Al}, \mathrm{O}_{2} / \mathrm{RP}-1 / \mathrm{Al}$ and $\mathrm{NTO} / \mathrm{MMH} / \mathrm{Al}$. Figure 1 shows the effect of metal loading on $I_{s p}$ for $O_{2} / R P-1 / A 1$, NTO/MMH $/ \mathrm{Al}$ and $\mathrm{O}_{2} / \mathrm{H}_{2} / \mathrm{Al}$. The peak $\mathrm{I}_{\mathrm{sp}}$ is produced at different metal loadings for each combination. The maximum $I_{\mathrm{sp}}$ points for the three propellant combinations were 65 percent in $\mathrm{O}_{2} / \mathrm{H}_{2} / \mathrm{Al}$ (for the SSME), 5 to 10 percent in $\mathrm{O}_{2} / \mathrm{RP}-1 / \mathrm{Al}$ and 40 percent in NTO/MMH/Al. Later in the paper, the selection of the "best" design points will be discussed. The "best" design is based on the vehicle design constraints, such as

ENGINE MIXTUAE RATIOS

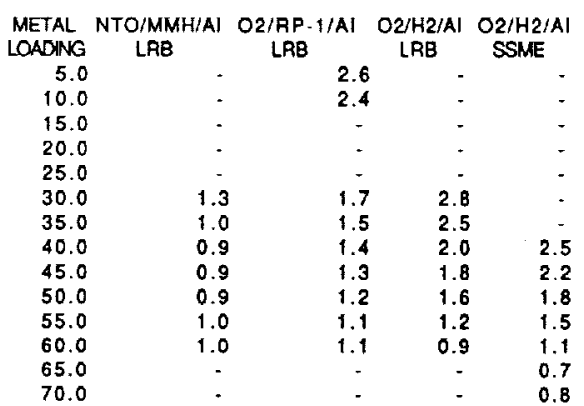

EXPANSION RATO:

$30: 1 \quad 30: 1 \quad 30: 1 \quad 77.5: 1$

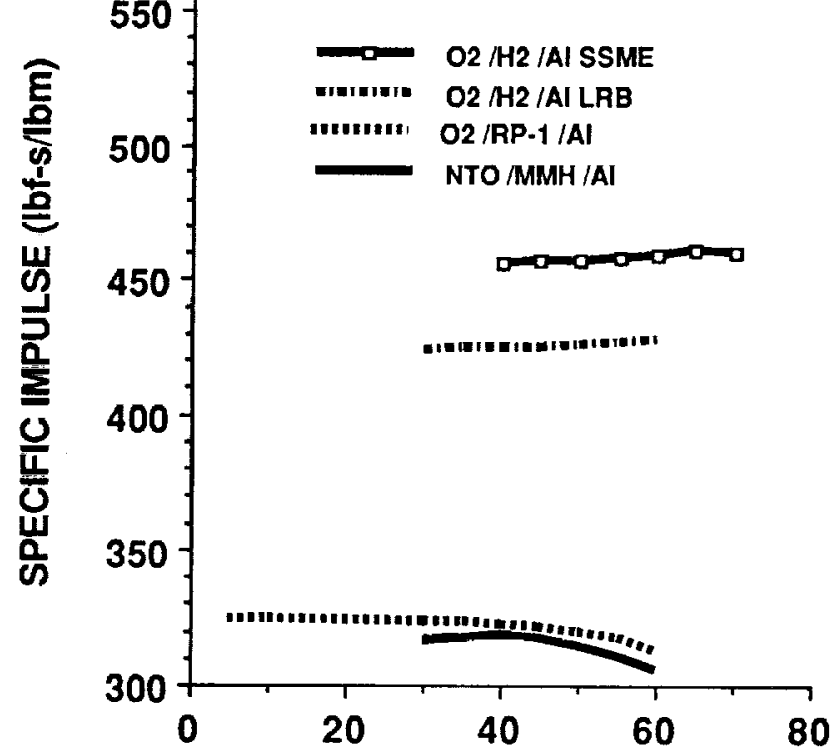

METAL LOADING

Figure 1. Specific Impulse vs. Metal Loading 
volume available for the LRB or other booster volume and not the maximal $I_{s p}$.

The NTO/MMH/Al systems are able to deliver the highest $I_{s p}$ increases over the nonmetallized cases. These results are shown in Table II. With the pump-fed LRB, the $I_{\mathrm{sp}}$ has risen $11.21 b_{\mathrm{f}}-\mathrm{s} / 1 \mathrm{~b}_{\mathrm{m}}$. Also, the NTO/A-50/Al propellants for the Titan IV provided a 9.2 $1 b_{f}-s / 1 b_{n} I_{s p}$ rise for stage 1 and a $141 b_{f-}^{-}$ $s / 1 b_{m}$ increase for stage 2 . The Titan engine performance using metallized NTO/A-50/Al requires a metal loading of 35 to 40 percent to produce the maximum $I_{s p}$ increase for these engines.

An important point to note is that the metallized cases with $\mathrm{O}_{2} / \mathrm{RP}-1 / \mathrm{Al}$ have a net $I_{s p}$ reduction over the non-metallized $\mathrm{O}_{2} / \mathrm{RP}-$ 1 combination. A small $I_{s p}$ drop also occurs with the pressure-fed NTO/MMH/Al system. Though the $I_{s p}$ is lowered with the addition of the metal, the density increase afforded with the 55-percent Al loading enables denser packaging of the booster. There will still be a performance gain even with a reduction in $I_{\mathrm{Bp}}$.

The maximal metal loading considered for $\mathrm{O}_{2} / \mathrm{H}_{2} / \mathrm{Al}$ was 70 percent of the fuel mass. The metal loading when considering of all of the propellant (oxidizer and fuel) of the $\mathrm{O}_{2} / \mathrm{H}_{2} / \mathrm{Al}$ propulsion system was 38.9 percent (for a mixture ratio of 0.8 with a 70 percent Al loading). The $\mathrm{O}_{2} / \mathrm{H}_{2} / \mathrm{Al}$ peak $\mathrm{I}_{\mathrm{sp}}$ was $461.21 b_{f}-5 / 1 b_{m}$ at a metal loading of 65 percent of $A 1$ in the $\mathrm{H}_{2} / \mathrm{Al}$ fuel, with an $\epsilon$ of $77.5: 1$ and a mixture ratio of 0.7 . Later in the paper, the reasons for selected an $I_{\text {sp }}$ other than the peak value will be analyzed.

With metallized $\mathrm{O}_{2} / \mathrm{H}_{2} / \mathrm{Al}$ (with 60 -percent $\mathrm{Al}$ loading) for the IRB, an $8.8-1 b_{t}-s / 1 b_{m}$ increase is enabled over $\mathrm{O}_{2} / \mathrm{H}_{2}$ (shown in Table II). This is a larger increase than that previously discussed for this propellant combination (Refs. 8 and 9). The difference stems from the fact that the $I_{B p}$ for $\mathrm{O}_{2} / \mathrm{H}_{2}$ and $\mathrm{O}_{2} / \mathrm{H}_{2} / \mathrm{Al}$ are not being compared at their respective maximum $I_{s p}$ points. The optimum ratio is near 4.0 to produce the maximum $\mathrm{O}_{2} / \mathrm{H}_{2} \mathrm{I}_{\mathrm{sp}}$ at the very low values of $\epsilon$ needed for the LRB. The 6.0 mixture ratio was selected for the IRB based on the results of References 11 and 12 . If the $I_{\mathrm{sp}}$ values of the metallized and non-metallized systems were compared at their respective maximum $I_{\mathrm{sp}}$ points, the performance increase for metalized propellants would be representative of the smaller differences reported in Refs. 8 and 9.

Propellant Density. Using the aluminum loadings considered in the engine performance calculations, the propellant density for the RP-1 can increase from 773 $\mathrm{kg} / \mathrm{m}^{3}$ to $1281 \mathrm{~kg} / \mathrm{m}^{3}$ ( 55 percent aluminum loading in the fuel). For $\mathrm{H}_{2}$ fuel, the density can increase from $70 \mathrm{~kg} / \mathrm{m}^{3}$ to 220.3 $\mathrm{kg} / \mathrm{m}^{3} \quad \mathrm{H}_{2}$ with a 70-percent aluminum loading). The density increase is computed using:

$$
\rho_{\mathrm{p}, \mathrm{m}}=\quad 1 /\left([1-\mathrm{ML}] / \rho_{\mathrm{p}}+\mathrm{ML} / \rho_{\mathrm{m}}\right)
$$

where:

$\begin{array}{ll}\rho_{\mathrm{p}, \mathrm{m}} & \begin{array}{l}\text { Density of Metallized Fuel } \\ \left(\mathrm{kg} / \mathrm{m}^{3}\right)\end{array} \\ \mathrm{ML} & \begin{array}{l}\text { Metal Loading (Fraction of } \\ \text { Fuel Mass) }\end{array} \\ \rho_{\mathrm{m}} & \begin{array}{l}\text { Density of Metal in the Fuel } \\ \left(\mathrm{kg} / \mathrm{m}^{3}\right)\end{array} \\ \rho_{\mathrm{p}} & \begin{array}{l}\text { Density of Nonmetallized Fuel } \\ \left(\mathrm{kg} / \mathrm{m}^{3}\right)\end{array}\end{array}$

Selection of the Best Density-I Design points. To fit the LRB into the volume of an SRB or deliver the maximal payload increase, trade studies must be conducted to determine the "best" $I_{s p}$ and density for each propulsion system. The selection of the metal loading was based on maximizing the vehicle payload or the ability to fit within an existing volume constraint.

At the peak $\mathrm{I}_{\mathrm{sp}}$ design point for $\mathrm{O}_{2} / \mathrm{H}_{2} / \mathrm{Al}$, the bulk density decreases slightly over that for $\mathrm{O}_{2} / \mathrm{H}_{2}$. The $\mathrm{O}_{2} / \mathrm{H}_{2} / \mathrm{Al}$ propellants may require a heavier propulsion system than the non-metalized design case. Reference 9 compares the propulsion mass scaling equations for several metal loadings. There is a small variation in the total mass of the propulsion system with the different metal loadings. Based on the Ref. 9 trade studies, the $I_{\text {sp }}$ that is representative of a metal loading of 60 percent was initially selected for the $\mathrm{O}_{2} / \mathrm{H}_{2} / \mathrm{AI}$ LRB. The metallized ET used a 70-percent metal loading. For all of the remaining metallized combinations, the metal loading was selected to allow the liquid booster to fit within the volume constraints of the existing propulsion systems. The remaining LRB propellant combinations produce an overall density increase.

If the benefits of reduced GLOW or increased payload are not desired or significant, the effects of increased propellant density can still be a benefit to launch vehicles. Because of the increased density, the propellant tankage size can be reduced, potentially offering better and smaller tank configurations. As an example, for the LRB using $\mathrm{O}_{2} / \mathrm{RP}-1 / \mathrm{Al}$, the propellant tank volume is reduced over that for the $\mathrm{O}_{2} / \mathrm{RP}-1$ case. In the metalized system (with a $49,6641 \mathrm{~b}_{\mathrm{m}}$ payload), the total propellant tank volume was reduced to $304.7 \mathrm{~m}^{3}$ from the $351.1 \mathrm{~m}^{3}$ required for the non-metallized $\mathrm{O}_{2} / \mathrm{RP}-1$ case.

Although the tankage volume decreased in the NTO/MMH/Al case, other applications of metallized propellants, such as $\mathrm{O}_{2} / \mathrm{H}_{2} / \mathrm{Al}$, will show a small tankage volume increase. This is due to the lower mixture ratio of the metallized $\mathrm{O}_{2} / \mathrm{H}_{2} / \mathrm{Al}$ system over the $\mathrm{O}_{2} / \mathrm{H}_{2}$ system. In the $\mathrm{O}_{2} / \mathrm{H}_{2} / \mathrm{Al} \mathrm{ET}$, the total $\mathrm{O}_{2}$ tank 
volume can be reduced from $553.9 \mathrm{~m}^{3}$ to 310 $\mathrm{m}^{3}$ for the metallized case. The $\mathrm{H}_{2}$ tank volume, however, increased from 1515.2 to $2022.8 \mathrm{~m}^{3}$ with metallized propellants. overall, the total tank volume increased from 2069 to $2333 \mathrm{~m}^{3}$ (a difference of 264 $\mathrm{m}^{3}$ or 12.8 percent). This example is for the case for the STS ET for both the metallized and the non-metallized $\mathrm{O}_{2} / \mathrm{H}_{2}$ systems where the payload to orbit was $22,527 \mathrm{~kg}(49,664$ $\left.1 b_{m}\right)$.

Pump-Fed and Pressure-Fed systems. With the very-high performance $\mathrm{O}_{2} / \mathrm{H}_{2}$ systems being considered for launch vehicles, a pump-fed engine may be required. Pressure-fed propulsion systems are also under consideration, but they typically require larger masses for propellant tankage and pressurization systems. Using metallized propellants, the propellant feed system must be designed to supply the non-Newtonian, thixotropic metaliized propellant with the same reliability as the non-metallized $\mathrm{H}_{2}$. Currently, metallized propellants are fed to small propulsion systems with positivedisplacement propeliant expulsion devices (diaphragms, etc., Ref. 26). A positive expulsion system and a pressure-fed system, however, are considered impractical and too massive for large propellant tanks. For the extremely-large propellant loads needed on launch vehicles, a way of effectively using pump-fed engines will be required. Preliminary pump and propellant expulsion work was conducted in previous research programs (Refs. 27 and 28). This work demonstrated the feasibility of pumping metallized fuels. Also, the research showed that very high expulsion efficiency could be achieved for metallized propellants without using positive-expulsion devices in the propellant tanks.

Mass Scaling Equations. In determining the dry mass of the launch vehicle stages, the following general mass-scaling equation was used:

$$
m_{d r y}=A+B m_{p}
$$

where:

$\mathbf{m}_{\mathrm{dry}}$

Dry Mass (kg)

$A, B$

Mass Parameters

$\mathbf{m}_{\mathrm{p}}$

Propellant Mass

(kg)

Table IV lists the propulsion mass-scaling parameters for all of the considered systems. These parameters include all of the masses that are required to store and deliver propellants to the main engines. They include tankage, engines, feed system, thermal control, structure, residuals and contingency. Also included, if needed, are the aerodynamic structure of the boosters, such as the nose cone and aft skirt of the LRB. These parameters were derived from the results of the LRB studies and the results of propellant-tank mass estimation codes used in previous studies (Refs. 8, 9 and

13). The parameter $A$ of the scaling equations varies due to the different engine, nose cone and aft skirt masses of the differing boosters. The $B$ parameter is dependent upon the propellant mixture ratios, the propellant metal loading and hence the propellant density. The specific mixture ratios and the metal loadings are listed in Table III.

All of the tankage configurations considered in the study were based on the ability to package the boosters within a current launch vehicle's length and diameter constraints. Typically the main tankage is cylindrical with ellipsoidal dome ends. only the pressurization systems used spherical tankage.

The propellant tankage for all of the pumpfed systems is designed for a 50-psia maximal operating pressure. The propellant is stored at 30 psia. Pressure-fed boosters had higher maximum operating pressures of 500 psia. All of the tankage for $\mathrm{O}_{2}, \mathrm{H}_{2}$ and RP- 1 is composed of aluminum alloy (2219T87). The LRB tanks for NTO and MMH are made of titanium $(\mathrm{Ti}-6 \mathrm{Al}-4 \mathrm{~V})$. The flange factor (for mounting flange masses) and safety factor are 1.4 and 2.0 , respectively, for the propellant tanks. The safety factor is based on the tank material ultimate stress. The propellant residuals and holdup mass is 1.5 percent of the total propellant mass. The percentage accommodates a small added

Table IV

Propulsion System Mass-Scaling Parameters: Dry Mass Per Booster

$\begin{array}{lcc}\text { Vehicle and } & \text { Scaling } \\ \text { Propellant } & \text { A } & \text { B }\end{array}$

\section{STS:}

Booster Options -

Solid

Pump-Fed :

$\mathrm{O}_{2} / \mathrm{RP}-1$

$\mathrm{O}_{2} / \mathrm{RP}-1 / \mathrm{AI}$

NTO/MMH

NTO/MMH $/$ A 1

$\mathrm{O}_{2} / \mathrm{H}_{2}$

$\mathrm{O}_{2} / \mathrm{H}_{2} / \mathrm{Al}$

$85,698.8$

$26,184.8$

$26,261.2$

$26,294.4$

$26,294.4$

$26,236.9$

$26,236.9$

Pressure-Fed :

$\mathrm{O}_{2} / \mathrm{RP}-1$

$\mathrm{O}_{2} / \mathrm{RP}-1 / \mathrm{Al}$

NTO/MMH

NTO/MMH/A I

Main Propulsion Options -

$\mathrm{O}_{2} / \mathrm{H}_{2}$

$\mathrm{O}_{2} / \mathrm{H}_{2} / \mathrm{Al}$

Titan IV:

Stage 1 Options -

NTO $/ \mathrm{A}-50$

Stage 2 Options -

NTO/A -50
$10,517.4$

0.0

$30,456.9$

$30,456.9$

$29,737.2$

$29,737.2$

0.0469
0.2009
0.1767
0.1463
0.1332

0.2009
0.1767
0.1463
0.1332

0.2009
0.1767
0.1463
0.1332

0.0747

0.0650

0.0642

0.0925

0.1016

0.0

$4,137.3 \quad 0.0$ 
propellant mass for cryogenic propellant boiloff. Because the stages have propellant ground support up until liftoff, no large allowance was made for propellant losses due to boiloff. The mass contingency for the boosters was 20 percent of the dry mass.

Each cryogenic $\mathrm{O}_{2} / \mathrm{H}_{2}$ propulsion system uses autogenous pressurization. The NTO/MMH system used regulated pressurization. The pressurant is helium. In the pressurant tank, the maximal operating pressure is 3722 psia. The storage pressure is 3444 psia (Ref. 9). The flange factor and safety factor for the pressurant tanks are 1.1 and 2.0 , respectively. For the autogenous systems, a small helium pressurization system is included. It can pressurize onetenth of the total propellant tank volume. For thermal control, the cryogenic propellants $\left(\mathrm{O}_{2}\right.$ and $\left.\mathrm{H}_{2}\right)$ use a highperformance multilayer insulation (Ref. 9). The storable propellants only require a lower-performance multilayer insulation.

The metallized $\mathrm{O}_{2} / \mathrm{H}_{2} / \mathrm{Al}$ ET also used the same design assumptions as the $\mathrm{O}_{2} / \mathrm{H}_{2} / \mathrm{Al} \mathrm{LRB}$. There were, however, two differences between the $\mathrm{LRB}$ and the ET. One was that the residual and holdup mass of the ET was 1 percent of the total propellant mass. Also, no small helium system was added. These changes over the LRB assumptions are based on the existing ET design.

\section{Mission Analysis}

On the sTs missions, the mission is described with two $\Delta V$ values. These values for the space shuttle missions carrying a $22,527 \mathrm{~kg}\left(49,664 \quad 1 \mathrm{~b}_{\mathrm{m}}\right)$ payload were 2.49 $\mathrm{km} / \mathrm{s}$ for the first-stage firing (SSME/SRB ignition to $\mathrm{SRB}$ separation) and $6.74 \mathrm{~km} / \mathrm{s}$ for the second stage (SRB separation to Main Engine cut off [MECO]). These $\Delta V$ values are based on the performance of the Ulysses launch mission (Ref. 15) and the performance predicted in past STS Liquid Rocket Booster studies (Refs. 11 and 12 ). The $\Delta V$ values for the other STS payloads are listed in Table V: 22,527 to $31,979 \mathrm{~kg}(49,664$ to 70,500 $\left.1 b_{m}\right)$. The final orbit of the orbiter is 296$\mathrm{km}$ ( 160 nautical mile) circular orbit with a 28.5-degree inclination, representative of a launch from the Kennedy space center. The firing to place the STS into its final circular orbit is provided by the orbital Maneuvering Subsystem (OMS) aboard the orbiter. The LRB-SSME performance places the vehicle into the same orbit as the ascent using the SRB-SSME combination. Because the OMS firing is the same in either ascent, this maneuver is not considered as part of this analysis.

On the Titan IV missions, trajectory simulations were used to predict the mission $\Delta V$ : the program for optimizing simulated Trajectories (POST) trajectory code (Ref. 29). The POST is a generalized eventoriented program that can be used to analyze ascent, on-orbit and entry trajectories. It can be used to optimize any calculated variable and the trajectory can be constrained to meet specified requirement.

The Titan IV vehicle used in the analysis is composed of a two-stage liquid propellant core and two seven-segment solid rocket motors (SRM). The configuration has no upper stage. The vehicle lifts off with only the SRMs firing. After SRM burnout, the liquid core is ignited at approximately 115 seconds after liftoff. Its final payload is placed in a circular orbit with a $407 \mathrm{~km}(220$ nautical mile) altitude and an inclination of 28.5 degrees. The launch is from the Eastern space and Missile center (Cape canaveral).

\section{Results}

\section{Space Transportation system}

For the STS, two types of propulsion system changes were studied. The first was the replacement of the SRBs with metallized and non-metallized LRBs. In the other study, the changeout of $\mathrm{O}_{2} / \mathrm{H}_{2}$ propellants for the SSME with metallized $\mathrm{O}_{2} / \mathrm{H}_{2} / \mathrm{Al}$ was analyzed.

\section{LRB for SRB Replacement}

$0_{2} / R P-1 / A 1$ LRB. The replacement of the SRB with $\mathrm{O}_{2} / \mathrm{RP}-1 / \mathrm{Al}$ allowed denser packaging of the booster within the SRB dimensions. Figure 2 contrasts the IRB length and diameter. The payload delivered to orbit is $22,527 \mathrm{~kg}\left(49,6641 \mathrm{~b}_{\mathrm{m}}\right.$, Ref. 15). If the booster is constrained to the diameter of the SRB, the $\mathrm{O}_{2} / \mathrm{RP}-1 / \mathrm{Al}$ booster is $43.4 \mathrm{~m}(142.3 \mathrm{ft})$ long: $2 \mathrm{~m}(6.7 \mathrm{ft})$ shorter than the SRB. Using $\mathrm{O}_{2} / \mathrm{RP}-1$, the booster is $47.6 \mathrm{~m}(156.3 \mathrm{ft})$ long; this length exceeds the $45 \mathrm{~m}(149-\mathrm{ft})$ SRB length.

Because the metallized LRB was smaller than the existing SRB, the sensitivity of booster size to payload-to-orbit was considered. In Figure 3, the LRB lengths are compared for four payload masses. Using a metal loading of 55 percent in the $O_{2} / R P-1 / A l$ LRB allowed the booster to fit within the existing SRB diameter and length and deliver almost

Table V

Launch Vehicle Design Assumptions: STS Mission $\Delta V$ Breakdown for LRB simulations

stage $\quad \Delta V(\mathrm{~km} / \mathrm{s})$

\begin{tabular}{lllll}
$\begin{array}{l}\text { Payload } \\
\left(\mathrm{kl} \mathrm{b}_{\text {m }}\right)\end{array}$ & 49.7 & 60.0 & 65.0 & 70.5 \\
\hline LRB & 2.4847 & 2.5894 & 2.6387 & 2.6920 \\
MPS & 6.7362 & 6.6315 & 6.5822 & 6.5289
\end{tabular}

* $\Delta \mathrm{V}$ varies for MPS and SRB due to fixed propellant load in ET 


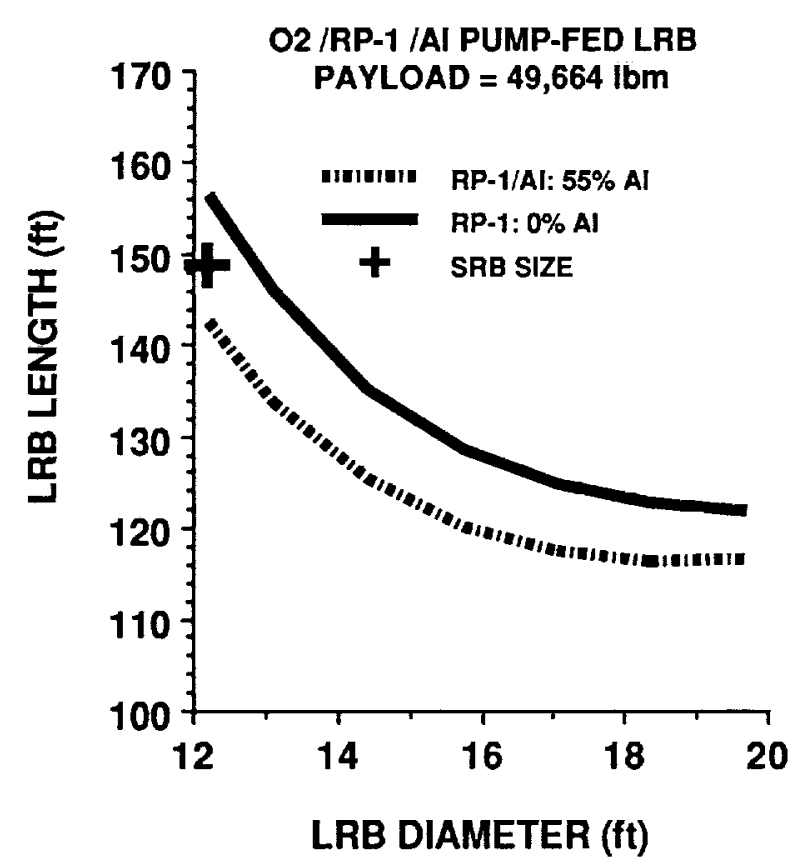

Figure 2. LRB Length vs. Diameter With $\mathrm{O}_{2} / \mathrm{RP}-1 / \mathrm{Al}$ : Payload $=49,664 \mathrm{lb} \mathrm{m}$

PRESSURE-FED LRB:

PAYLOAD $=49,664 \mathrm{lbm}$

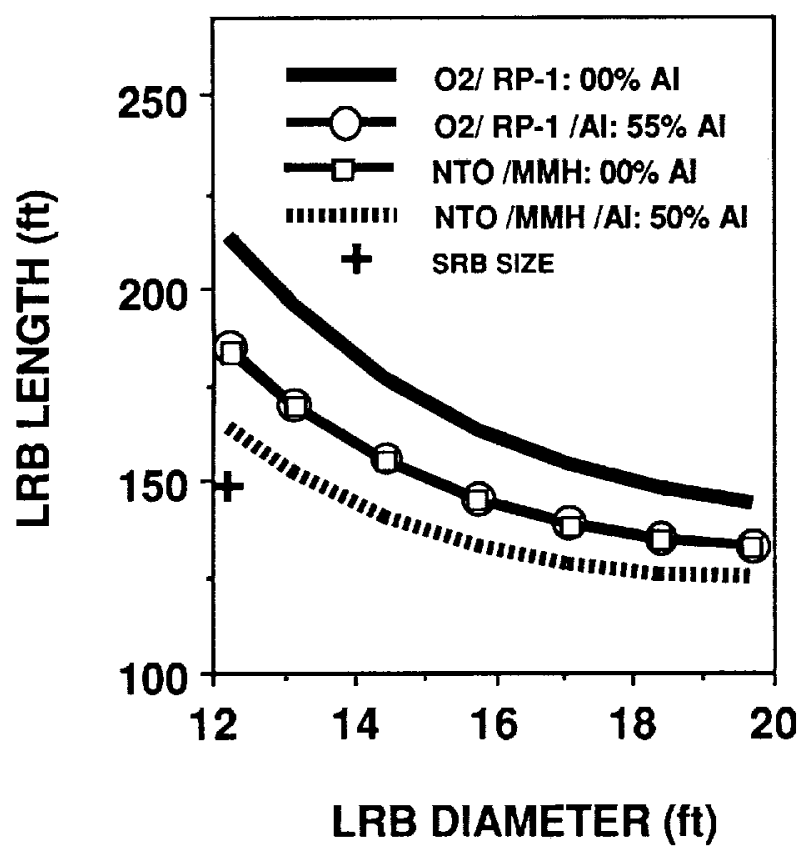

Figure 4. LRB Length vs. Diameter With Pressure-Fed Booster

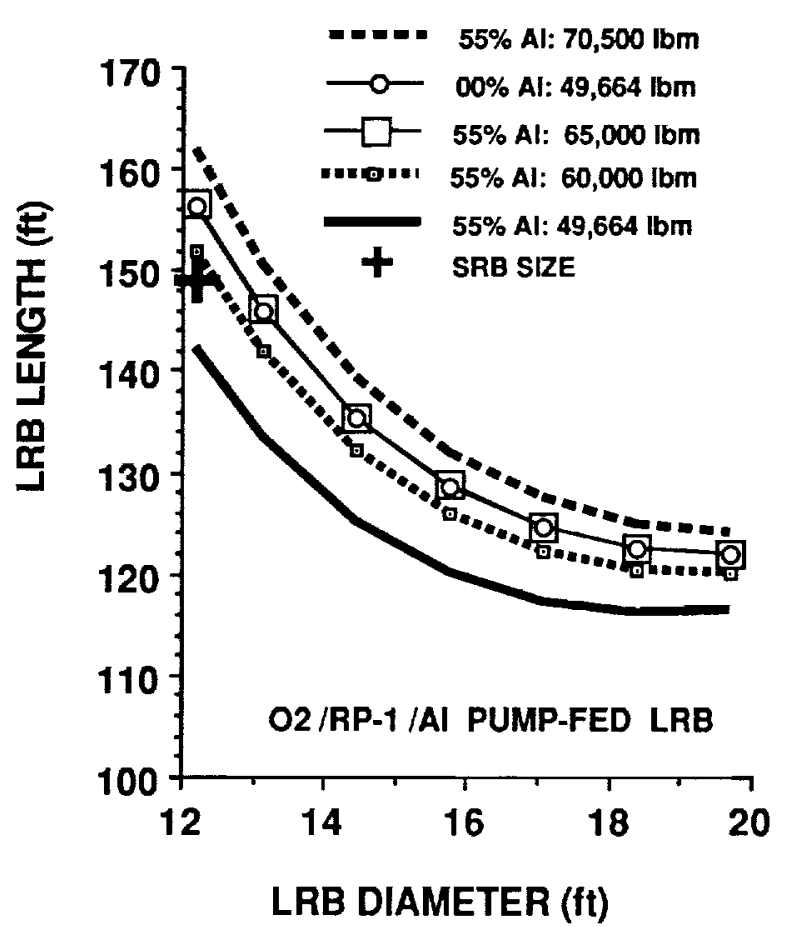

Figure 3. LRB Length vs. Diameter With $\mathrm{O}_{2} / \mathrm{RP}-1 / \mathrm{Al}$ - Payload Mass Parametrics

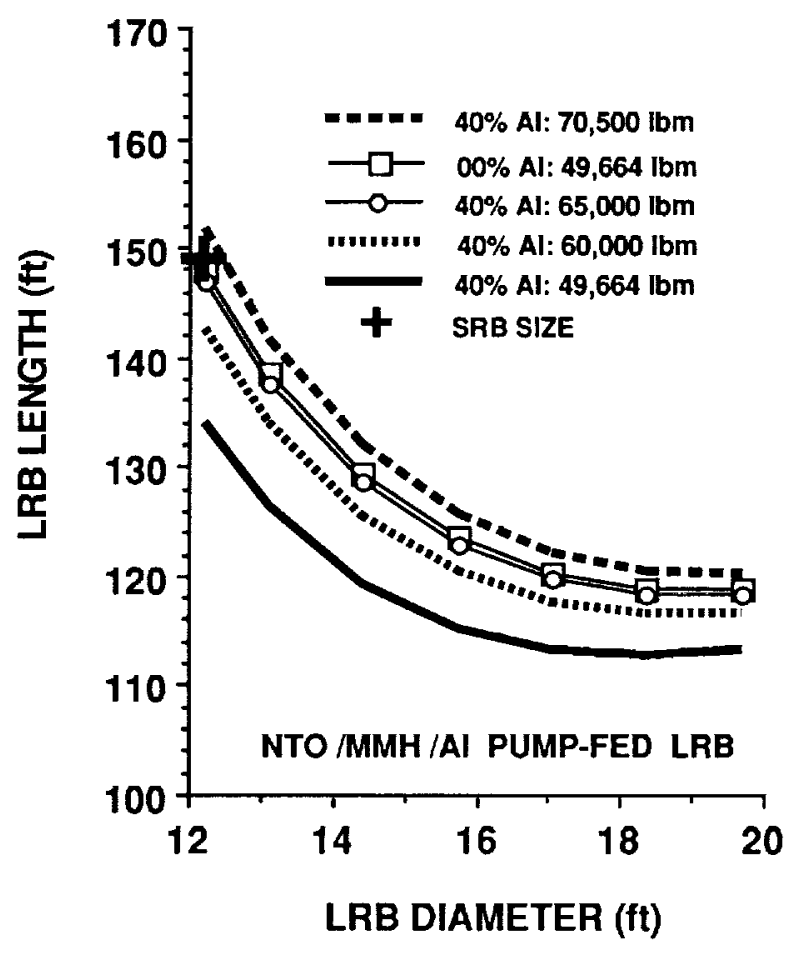

Figure 5. LRB Length vs. Diameter With NTO/MMH/Al - Payload Mass Parametrics 
$27,216 \mathrm{~kg}\left(60,000 \quad 1 \mathrm{~b}_{\mathrm{m}}\right)$ of payload; only 0.9 I $(2.9 \mathrm{ft})$ of added length is required to deliver that payload. By allowing the LRB length to increase to $49.3 \mathrm{~m}(161.9 \mathrm{ft})$, the payload to orbit can be increased to 31,979 $\mathrm{kg}\left(70,5001 \mathrm{~b}_{\mathrm{m}}\right)$. This is a 42 percent payload increase over the STS-with-SRB payload capability. While these lengths do violate the strict SRB length, these results are included to show the potential payload advantages of longer metallized LRBs.

A pressure-fed $\mathrm{O}_{2} / \mathrm{RP}-1 / \mathrm{Al}$ LRB was also investigated. The length and diameter of these boosters were not compatible with the SRB constraints. The metallized LRB is, however, substantially shorter than the nonmetallized booster. Figure 4 contrasts the pressure-fed boosters with the a 55-percent metal loading. The LRB length (when using the SRB diameter) is $56.3 \mathrm{~m}(184.7 \mathrm{ft})$. The corresponding $\mathrm{O}_{2} / \mathrm{RP}-1$ LRB length is $65 \mathrm{~m}$ $(213.4 \mathrm{ft})$.

$\mathrm{NTO} / \mathrm{MMH} / \mathrm{Al}$ LRB. As with the $\mathrm{O}_{2} / \mathrm{RP}-$ 1/Al boosters, the higher density of the metallized NTO/MMH/Al resulted in a very small LRB: only $40.8 \mathrm{~m}(134 \mathrm{ft})$ long. In Figure 5, the booster length and diameter are depicted. The metal loading selected for the MMH was 40 percent. The NTO/MMH/AI booster could deliver a $31,979 \mathrm{~kg}(70,500$ $\left.1 b_{m}\right)$ payload if the booster length were increased to $46.2 \mathrm{~m}(151.6 \mathrm{ft})$; this is only $0.8 \mathrm{~m}(2.6 \mathrm{ft})$ over the existing SRB dimensions.

The length and diameter of a pressure-fed NTO/MMH/Al booster with a 50-percent metal loading is shown in Figure 4. A higher metal loading than that for the pump-fed booster was used in this LRB to attempt to fit it within the SRB size. At this loading, the booster was unable to fit in the SRB length unless the LRB diameter was greater than 4 m (13 ft). The pressure-fed LRB is not considered a prime candidate for an SRB replacement.

$\mathrm{O}_{2} \angle \mathrm{H}_{2} \angle \mathrm{Al}$ LRB. There was little volume benefit from the pump-fed $\mathrm{O}_{2} / \mathrm{H}_{2}$ or $\mathrm{O}_{2} / \mathrm{H}_{2} / \mathrm{AI}$ LRB. This LRB was not able to meet the SRB sizing requirement. The length of the LRB without metallized propellants was $80.6 \mathrm{~m}(264.5 \mathrm{ft})$. With metallized $\mathrm{O}_{2} / \mathrm{H}_{2} / \mathrm{Al}$ (60-percent metal loading), the booster length was $96.3 \mathrm{~m}(315.8 \mathrm{ft})$. This is substantially longer than the 45.4-m (149ft) SRB length. The metallized booster length was equal to the SRB only at diameters much greater than $6.1 \mathrm{~m}(20 \mathrm{ft})$. Thus, the $\mathrm{O}_{2} / \mathrm{H}_{2}$ and the $\mathrm{O}_{2} / \mathrm{H}_{2} / \mathrm{Al}$ boosters were poor performers when using the SRB sizing constraints.

For pump-fed booster engines, the nozzle expansion ratio is small: 30:1. When using the low expansion ratios required for the $\mathrm{O}_{2} / \mathrm{H}_{2} / \mathrm{Al}$ LRB engines, the maximum $\mathrm{I}_{\mathrm{sp}}$ for the metallized propellants occur at a low mixture ratio. This low mixture ratio forces the tank's total volume to be greater than that for the $\mathrm{O}_{2} / \mathrm{H}_{2}$ system at a $6: 1$ oxidizer to fuel ratio.
If the volume constraints of the LRB were relaxed, $\mathrm{O}_{2} / \mathrm{H}_{2} / \mathrm{Al}$ propellants may provide a payload increase and a GLOW reduction. Future vehicle studies may therefore find these metallized propellants as an attractive option.

LRB Masses. Table VI compares the $\mathrm{O}_{2} / \mathrm{RP}-1 / \mathrm{Al}$ and NTO/MMH/AI LRB masses. These boosters were sized for the baseline payload mission. Each of the boosters is substantially lighter than the SRB. The GLOW of these options was therefore lower than the standard STS-SRB vehicle. The $\mathrm{O}_{2} / \mathrm{RP}-1 / \mathrm{Al}$ case reduced the GLOW by 19 percent (or $394,500 \mathrm{~kg}$ ) and the NTO/MMH/Al case was able to reduce the GLOW by 20 percent (or 411,881 $\mathrm{kg}$ ) A lower GLOW can make processing of the vehicle easier and transportation of the vehicle elements easier in the processing flow.

Specific Impulse Efficiency (n) Effects on LRB Length. The influence of $\eta$ on the performance of the metallized launch vehicles was investigated. Due to the twophase flow of the metallized propellants in the combustion chamber and nozzle, there is a difference between the gas and solidliquid particle velocities which creates a performance loss. The solid-liquid particles are composed of solid and liquid aluminum oxide $\left(\mathrm{Al}_{2} \mathrm{O}_{3}\right)$. Once the potential losses of metallized propellants are introduced into the analysis, the performance may be much lower than that previously predicted. A

Table VI

Liquid Rocket Booster Mass Summary: Metallized 02/RP-1/A1 and NTO/MMH/Al Propellants

Subsystem

$$
\mathrm{O}_{2} / \mathrm{RP}-\mathrm{I} / \mathrm{Al} \text { Mass } \underset{\mathrm{NTO} / \mathrm{MMH} / \mathrm{Al}}{(\mathrm{kg})}
$$

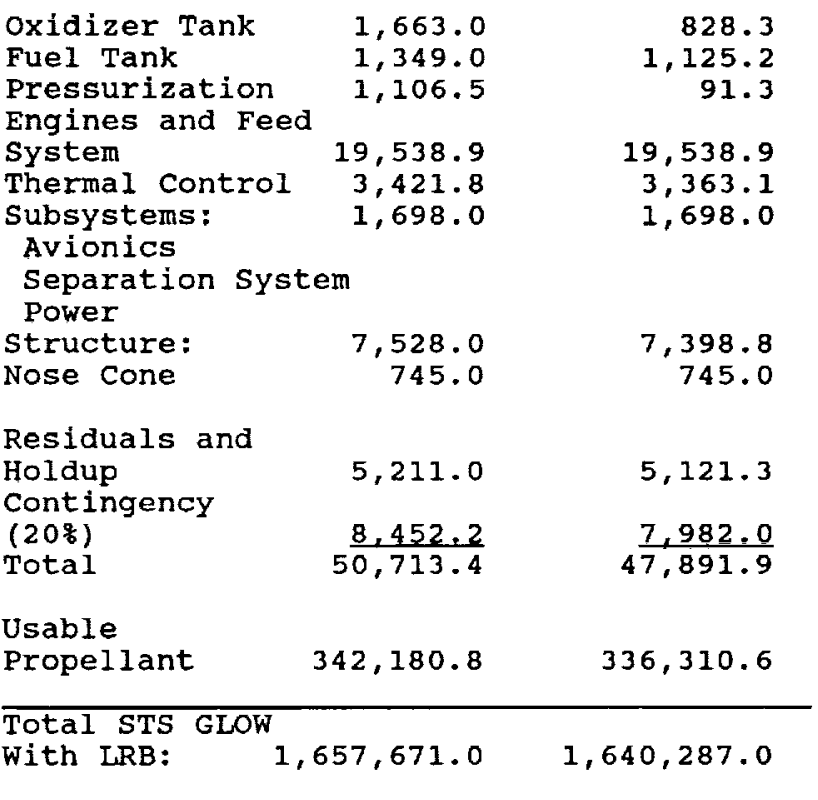


series of cases showing this influence on the $\mathrm{O}_{2} / \mathrm{RP}-1 / \mathrm{Al}$ and $\mathrm{NTO} / \mathrm{MMH} / \mathrm{Al}$ systems were analyzed and the results are discussed below.

$\underline{O}_{2} / \mathrm{RP}-1 / \mathrm{Al} n$ Effects. Figure 6 provides the parametrics of IRB length and $\eta$ for $\mathrm{O}_{2} / \mathrm{RP}-1 / \mathrm{A} 1$ propellants. In the figure, the metallized $\eta$ is varied from 0.87 to 0.92 . This range reflects the performance penalties that have been predicted for metallized propellants: up to a five percent reduction in $\eta$ (Refs. 22 and 30 ). The LRB length is $46 \mathrm{~m}$ (151 ft) with the worst-case $\eta$. Even with an $\eta$ penalty of 4 percent ( $\eta=$ 0.88 ), the $\mathrm{O}_{2} / \mathrm{RP}-1 / \mathrm{Al}$ LRB is able to fit within the $S R B$ length requirement. This case is for the baseline payload of $22,527 \mathrm{~kg}$ $\left(49,6641 b_{m}\right)$.

NTO/MMH/Al $n$ Effects. The overall effect of reduced $n$ is least detrimental for NTO/MMH/Al propeliants. Figure 6 provides the parametrics of booster length and $\eta$ for NTO/MMH/A1. A $\eta$ range of 0.87 to 0.92 was used. As with the results for $O_{2} / R P-1 / A I$ discussed above, the NTO/MMH/Al booster for the STS with the baseline $22,527 \mathrm{~kg}(49,664$ $1 b_{m}$ ) payload is able to fit within the SRB length and diameter. With the metallized NTO/MMH/Al for the baseline payload, the length is $43.2 \mathrm{~m}(141.8 \mathrm{ft})$ for the worstcase penalty of $\eta=0.87$.

clearly, the $\eta$ will have a very strong influence on reducing the LRB size in some of the metallized cases. This is especially true for the higher payload cases. A penalty of the magnitude predicted for metallized propellants can seriously reduce their benefits. Small reductions in the $\eta$, however, can be absorbed with only a small booster length increase. Research on reducing the losses associated with metallized systems has been conducted (Refs. 25 and 31 ). Reducing the $\mathrm{Al}_{2} \mathrm{O}_{3}$ particle size will reduce the gas and solid-liquid velocity differences, improve the metallized $\eta$ and improve the delivered payload and reduce the LRB size. If the metallized LRB does experience large $\pi$ penalties, and cannot deliver added payload, there are still benefits to be gained. The increased safety offered by gelled metallized propellants and the controllability enabled with an LRB makes a metallized booster an important safety enhancement.

\section{Main Propulsion System Replacement}

The performance of an SSME using metallized $\mathrm{O}_{2} / \mathrm{H}_{2} / \mathrm{Al}$ is shown in Figure 1 . At a 70percent $A I$ loading, the $I_{\mathbf{s p}}$ is increased from 452.66 to $460.61 \quad 1 b_{f}-s / 1 b_{m}$. This metal loading was selected after analyzing a range of loadings from 40 to 70 percent. A $70-$ percent loading produced the smallest volume increase of the ET. Figure 7 depicts the performance of the STS with the metallized SSMEs. Standard SRBs are used in this analysis. Two levels of contingency (or masses that are added to the ET dry mass) are shown: 0 and 20 percent. The variation in contingency was shown to demonstrate the
PAYLOAD $=49,664 \mathrm{lbm}$

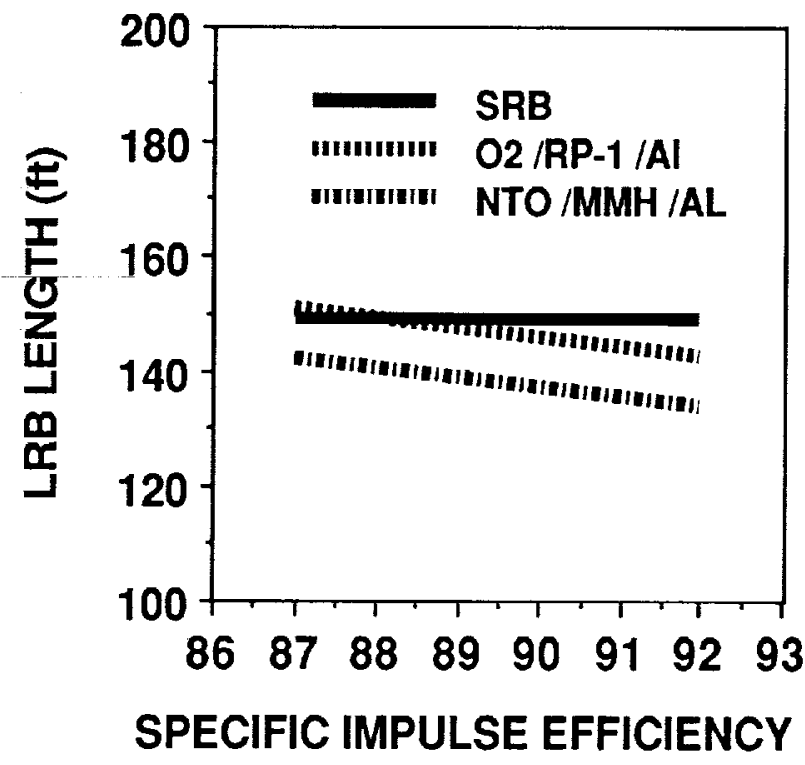

Figure 6. LRB Length vs. Isp Efficiency

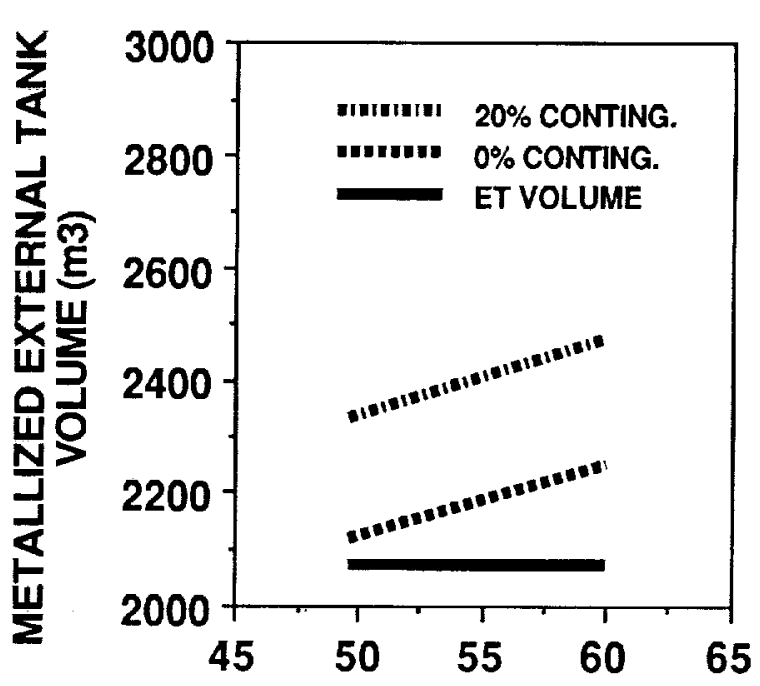

PAYLOAD MASS (1000 lbm)

Figure 7. Metallized ET Volume vs. Payload 
influence of the dry mass on performance. A performance increase was enabled with metallized $\mathrm{O}_{2} / \mathrm{H}_{2} / \mathrm{Al}$ but not without increasing the ET volume. With these propellants, the mixture ratio of the propulsion systems was very low: 0.8 . As with the $\mathrm{O}_{2} / \mathrm{H}_{2} / \mathrm{Al}$ LRB analysis, the volume of the metallized $E T$ is larger than the standard ET. Because the mixture ratio of the $\mathrm{O}_{2} / \mathrm{H}_{2} / \mathrm{Al}$ system (with $708 \mathrm{Al}$ in $\mathrm{H}_{2} / \mathrm{Al}$ ) is so low, the tankage volume was increased by 8.7 percent over the ET for the baseline payload (0-percent contingency). Even with the increased density of the $\mathrm{H}_{2} / \mathrm{Al}$, the metallized system was not able to fit within the ET volume constraint.

For the cases where the 20-percent mass contingency was added to the dry mass of the metallized ET, metallized propellants provided a payload advantage but with a larger volume increase. Because of the important influence of the ET mass contingency on vehicle performance, a better understanding of this mass is needed. Once the design features of this new tank are more refined, the analyst will be able to more clearly define the contingency mass. More detailed payload analyses can then be conducted to find the benefit of metallized $\mathrm{O}_{2} / \mathrm{H}_{2} / \mathrm{Al}$. The added volume of the metallized ET, however, may make it impractical to include metallized $\mathrm{O}_{2} / \mathrm{H}_{2} / \mathrm{A} 1$ into the current STS. Future versions of heavy lift launch vehicles with more flexible volume constraints may more readily benefit from the $I_{s p}$ increase afforded by metallized $\mathrm{H}_{2} / \mathrm{A} 1$.

\section{Titan IV}

In the Titan IV simulations, the total vehicle weight (launch vehicle minus the payload) remained constant. Thus, the vehicle dry mass and the total propellant loads for both the metallized and nonmetallized core stages are the same. No replacements of the SRMs were considered. Using these propellant loads, the added payload to orbit was calculated. Table VII compares the payloads for the two cases. Using metallized NTO/A-50/Al, the payload was increased from $14,643.0$ to $16,336.3 \mathrm{~kg}$ (an increase of 11.6 percent). In a comparison where the GLOW of the two vehicles were equal, the Titan payload was increased to $16,286 \mathrm{~kg}$, or 11.2 -percent higher than the non-metallized case. An analysis of the $\eta$ effect on the Titan payload was not conducted. As with the LRB, even if the payload to orbit is not significantly increased, the added safety benefits of gelled propellants may be as important as potential payload increases.

To take advantage of metallized propellants, the Titan IV would have to have several major modifications. Though the same total propellant mass is used in each of the stages, the volumes of the oxidizer and the metallized $A-50 / A 1$ fuel are different from those for the A-50 fuel. With the 0.68 mixture ratio for the metaliized Titan first stage, the total propellant volume needed is
Table VII

Titan IV Mass Summary:

NTO/A-50 and Metallized NTO/A-50/Al Propellants*

Vehicle

Mass (kg)

Element

No Metal

Metallized

Payload

$14,643.0$

$16,336.3$

Stage 2:

Propellant

$4,137.3$

$4,137.3$

Stage 1:

Dry

Propellant

$9,235.2$

$154,465.7$

$9,235.2$

Stage 0 :

Total Mass

$631,393.0$

$\underline{631.393 .0}$

Total

$848,524.5$

$850,217.8$

‡ Propeliant Masses Aboard the Stages 1 and 2 Are Identical

$121.61 \mathrm{~m}^{3}$. The volume available in the first stage is $126.72 \mathrm{~m}^{3}$. The volume split of the oxidizer and fuel however is incompatible with the existing tankage volumes. Therefore, the tank dome locations would have to be changed to accommodate the new propellants. The overall stage dimensions, however, are unchanged.

Also the combustion temperature of the metallized Titan engines will be somewhat higher than the existing engines. For the first stage, the predicted metallized combustion temperatures (35-percent $\mathrm{Al}$ in $\mathrm{A}-$ $50 / A 1)$ and the existing Titan engine temperatures are 3,419 and $3,336 \mathrm{~K}$, respectively. Additional cooling will have to be provided to the engine. other modifications would be needed for the vehicle feed lines, propellant acquisition system and the engine turbomachinery.

\section{Concluding Remarks}

Metallized propellants offer several options for the system designer looking for ways to improve the space shuttle's payload capacity and its safety. The benefits of metallized propellants for the STS LRB lie in the ability to fit a liquid propulsion system into the existing volume of the SRB. With metal loadings that are greater than 55 percent, $\mathrm{O}_{2} / \mathrm{RP}-1 / \mathrm{Al}$ propellants allow the LRB to fit within the existing SRB length and diameter. An NTO/MMH/Al LRB with a 40percent metal loading could deliver an even smaller LRB than the $\mathrm{O}_{2} / \mathrm{RP}-1 / \mathrm{Al}$ booster. This case is for the baseline payload of $22,527 \mathrm{~kg}\left(49,664 \quad 1 \mathrm{~b}_{\mathrm{m}}\right)$.

Even when the potential added two-phase flow losses with metallized propeliants are included, the LRB ís still able to fit within the SRB constraints. Even with an $\eta$ 
penalty of 4 percent $(\eta=0.88)$, the $\mathrm{O}_{2} / \mathrm{RP}-$ $1 / A 1$ LRB is able to fit within the SRB length and diameter requirement. This is for the case using the baseline STS payload of $22,527 \mathrm{~kg}\left(49,664 \quad 1 \mathrm{~b}_{\mathrm{m}}\right)$. Similarly, with the metallized NTO/MMH/AI for the baseline STS payload, the length is well within the SRB length. The booster length is only $43.2 \mathrm{~m}$ $(141.8 \mathrm{ft})$ for the worst-case penalty of $\eta$ $=0.87$.

When the losses from metallized propellants are minimal, the IRB can be shorter than the current SRB while delivering the baseline payload. If the metallized IRB used the full length of the SRB, the STS payload may be increased to $25,674 \mathrm{~kg}(56,600 \mathrm{~kg})$ with $\mathrm{O}_{2} / \mathrm{RP}-1 / \mathrm{Al}$. A payload of $30,482 \mathrm{~kg}(67,200$ $\left.1 b_{m}\right)$ is projected using a metallized NTO/MMH/AI IRB.

By relaxing the SRB volume requirements, there are significant added payload benefits enabled with metallized propellants for the STS over the existing SRB. If the LRB length were increased $0.9 \mathrm{~m}(2.9 \mathrm{ft})$, nearly 27,216 $\mathrm{kg}(60,0001 \mathrm{~b})$ of payload could be delivered using $\mathrm{O}_{2} / \mathrm{RP}-1 / \mathrm{Al}$ rather than the baseline payload of $22,527 \mathrm{~kg}\left(49,6641 \mathrm{~b}_{\mathrm{m}}\right)$. With NTO/MMH/Al, the STS payload could grow to $31,979 \mathrm{~kg}\left(70,500 \quad \mathrm{lb}_{\mathrm{m}}\right)$ if the LRB were $0.8 \mathrm{~m}(2.6 \mathrm{ft})$ longer than the current SRB.

With metalized propellants for the LRB, propellant density plays a critical role in allowing liquid propulsion systems to meet the demanding volume constraints of the STS $S R B$. Even though the $I_{3 p}$ of the $O_{2} / R P-1 / A l$ engine suffers a reduction over its nonmetallized counterpart, both these propellants and NTO/MMH/Al are able to enhance the sTs payload capability while remaining within the SRB volume. Future design studies of STS enhancements may, therefore, wish to include metallized propellants as a serious propulsion option.

Using metallized $\mathrm{O}_{2} / \mathrm{H}_{2} / \mathrm{Al}$ (with a 70-percent metal loading in the $\mathrm{H}_{2} / \mathrm{Al}$ ) in a derivative of the SSME can also increase the payload capacity of the STS. The volume of the External Tank using metallized propellants could not fit within the current tank volume constraints. Future launch vehicles that have less-stringent volume constraints could more-readily benefit from metallized $\mathrm{O}_{2} / \mathrm{H}_{2} / \mathrm{Al}$.

An 11.2 to 11.6 -percent increase in the Titan IV payload to LEO is enabled with metallized NTO/A-50/AI propellants. Several modifications will have to be made to the Titan stage to accommodate metallized NTO/A50/Al. The most significant of these are the relocation of the tank domes to resize the propellant tanks and the engine modifications for increased combustion temperature.

\section{Acknowledgement}

We would like to thank Mr. Ed Hooks of Martin Marietta Manned space systems for providing mass and configuration information on the STS External Tank.

\section{References}

1) Meyers, J.F., "Delta II - A New Generation Begins," McDonnell Douglas, AIAA Paper 89-2740, presented at the AIAA/ASME/SAE/ASEE 25th Joint Propulsion Conference, Monterey, CA, July 10-12, 1989.

2) "Phase A Report: Preliminary Assessment of Space Transportation Alternatives For Planetary Missions, " Jet Propulsion Laboratory, JPL Document D-3332, May $15,1986$.

3) Wormington, J., "Technical Baseline Document, Advanced Launch System (ALS)," U. S. Air Force Astronautics Laboratory, May 15, 1988.

4) Harsh, M, "Shuttle-C, Evolution to a Heavy Lift Launch Vehicle," NASA Marshall space Flight Center, AIAA Paper 89-2521, AIAA/ASME/SAE/ASEE 25th Joint Propulsion Conference, Monterey, CA, July 10-12, 1989.

5) "Study Requirements Document," NASA office of Exploration, Document Number 2-2.1-002, March 3, 1989.

6) Durocher, c., "National Space Transportation and support Study, Annex A, DoD Space Transportation Mission Needs," prepared by the DoD Mission Requirements Team, Draft Report, Air Force Space Division, May, 1986.

7) Jones, $\mathrm{K}$, et al., "Advanced Solid Rocket Motor," NASA Marshall Space Filght Center, AIAA Paper 89-2621, presented at the AIAA/ASME/SAE/ASEE 25 th Joint Propulsion Conference, Monterey, CA, July 10-12, 1989.

8) Palaszewski, B., "Lunar Missions Using Advanced Chemical Propulsion: System Design Issues," NASA Lewis Research Center, NASA TP-3065, AIAA Paper 902431, presented at the 26th AIAA/ASME/SAE/ASEE Joint Propulsion Conference, orlando, FL, July 16-18, 1990.

9) Palaszewski, B., "Metallized Propellants for the Human Exploration of Mars," NASA Lewis Research Center, NASA TP-3062, presented at the Case for Mars IV Conference, Boulder, CO, June $4-8,1990$.

10) "Space Transfer Concepts and Analysis for Exploration Missions - Third Quarterly Review, " Boeing Aerospace and Electronics, NASA Contract NAS8-37857, June $22,1990$.

11) "Liquid Rocket Booster (LRB) for the Space Transportation system (STS) Systems Study Final Report, Volume II," Martin Marietta Astronautics Group, NAS8-37136, March 1989. 
12) "Liquid Rocket Booster study - Volume II, Final Report," General Dynamics Space Systems Division, NAS8-37137, 1988.

13) Palaszewski, B., "Advanced Launch Vehicle Upper Stages Using Liquid Propulsion and Metallized Propellants," NASA Lewis Research Center, NASA TM103622 , presented at the 1990 JANNAF Propulsion Meeting, Anaheim, CA, October 3-5, 1990.

14) Haun, D.V., et al., "Insensitive Munitions Testing of Thixotropic Gels," Talley Defense systems, CPIA Publication 515, Volume III, presented at the 1989 JANNAF Propulsion Meeting, cleveland, OH, May 23-25, 1989.

15) White, R., "Shuttle systems weight and Performance," status Report, NASA Johnson Space Center, Report Number NSTS-09095-96, March 13, 1990.

16) "Press Information: Space Shuttle Transportation System," Rockwell International, March 1982.

17) Gordon, S. and McBride, B., "Computer Program for calculation of Complex Chemical Equilibrium Compositions, Rocket Performance, Incident and Reflected Shocks, and Chapman-Joguet Detonations," NASA Lewis Research Center, NASÁ SP-273, Interim Revision, March 1976.

18) Hannum, N., et al., "NASA's Chemical Transfer Propulsion Program for Pathfinder," NASA Lewis Research Center, NASA Technical Memorandum 102298, AIAA Paper 89-2298, presented at the AIAA/ASME/SAE/ASEE 25th Joint Propulsion Conference, Monterey, CA, July 10-12, 1989.

19) "Liquid Rocket Booster (LRB) for the space Transportation system (STS) systems study - Performance Review," Martin Marietta, Document DR-2, Contract Number NAS8-37136, March 1988.

20) Tamura, H., et al., "High Pressure Lox/Heavy Hydrocarbon Fuel Rocket Combustor Investigation," Proceedings of the Sixteenth International Symposium on space Technology and Science, Volume I, Sapporo, Japan, 1988 .

21) McMillion, R., et al., "Component Evaluations for the XLR-132 Advanced Storable Spacecraft Engine," Rockwell International/ Rocketdyne Division, AIAA Paper 85-1228, presented at the 21 st AIAA/SAE/ASME/ASEE Joint Propulsion Conference, Monterey, CA, July 8-10, 1985.

22) Galecki, D., "Ignition and Combustion of Metallized Propellants, "NASA-Lewis Research Center, AIAA Paper 89-2883, presented at the 25th AIAA/ASME/
SAE/ASEE Joint Propulsion Conference, Monterey, CA, July 10-12, 1989.

23) Vanderwall, E., et al., "Characterization of Gelled RP-1 Containing Aluminum," Aerojet Techsystems, presented at the JANNAF Propellant Development and characterization Subcommittee Meeting, Laurel, MD, November 28-December 1, 1989.

24) Chew, W., et al., "Propulsion systems Hazard Evaluation an Liquid/Gel Propulsion Component Development Formulation and characterization of Al/RP-1 Thixotropic Metallized Fuels," TRW Inc., Final Report, Contract Number DAAH-01-86-C-0114, October 3, 1989.

25) Wong, s., et al., "Disruptive Burning of Aluminum/Carbon Slurry Droplets," Pennsylvania state University, in Combustion science and Technology, volume 66, pp. 75-92, 1989.

26) Giola, G., et al., "Advanced Gel (AGEL) Technology Program," TRW Inc., presented at the JANNAF Propulsion Meeting, cleveland, $O H$, May 23-25, 1989 .

27) Salzwedel, R., et al., "Propellant Utilization outflow and Adherence," Martin Marietta Corporation, in the Second Metallized Gelled propellants Conference, Chemical Propulsion Information Agency (CPIA), conference held at the Air Force Rocket Propulsion Laboratory, August 26-28, 1964.

28) Chlapek, J., et al., "Thixotropic Simulation Pumping Technology," Air Force Rocket Propulsion Laboratory, in the Second Metallized Gelled Propellants Conference, Chemical Propulsion Information Agency (CPIA), conference held at the Air Force Rocket Propulsion Laboratory, August 26-28, 1964.

29) Brauer, G. L., et al., "Capabilities and Applications of the Program to optimize simulated Trajectories (POST)," NASA Contractor Report 2770, February 1977 .

30) Hester, J. N., et al., "Specific Impulse of a Metallized Propellant," Aerojet-General corporation, in the Second Metallized Gelled Propellants Conference, Chemical Propulsion Information Agency (CPIA), conference held at the Air Force Rocket Propulsion Laboratory, August 26-28, 1964.

31) Turns, S., et al, "Secondary Atomization of Aluminum/RP-1 Liquid Rocket slurry Fuels," presented at the Eastern section: The Combustion Institute - Fall Technical Meeting 1990, Orlando, FL, December 3-5, 1990. 
1. Report No. NASA TM- 104456

AIAA - 91-2050

4. Title and Subtille 5. Report Date

Launch Vehicle Performance Using Metallized Propellants

\begin{tabular}{|c|c|}
\hline & 6. Performing Organization Code \\
\hline \multirow[t]{2}{*}{$\begin{array}{l}\text { 7. Author(s) } \\
\text { Bryan Palaszewski and Richard Powell }\end{array}$} & $\begin{array}{l}\text { 8. Performing Organization Report No. } \\
\text { E-6297 }\end{array}$ \\
\hline & $\begin{array}{l}\text { 10. Work Unit No. } \\
506-42\end{array}$ \\
\hline $\begin{array}{l}\text { 9. Performing Organization Name and Address } \\
\text { National Aeronautics and Space Administration } \\
\text { Lewis Research Center } \\
\text { Cleveland, Ohio } 44135-3191\end{array}$ & 11. Contract or Grant No. \\
\hline \multirow{2}{*}{$\begin{array}{l}\text { 12. Sponsoring Agency Name and Address } \\
\text { National Aeronautics and Space Administration } \\
\text { Washington, D.C. 20546-0001 }\end{array}$} & Technical Memorandum \\
\hline & 14. Sponsoring Agency Code \\
\hline
\end{tabular}

15. Supplementary Notes

Prepared for the 27th Joint Propulsion Conference cosponsored by the AIAA, SAE, ASME, and ASEE, Sacramento, California, June 24-27, 1991. Bryan Palaszewski, NASA Lewis Research Center. Richard Powell, NASA Langley Rescarch Center, Hampton, Virginia 236-5225. Responsible person, Bryan Palaszewski, (216) 433-2439.

16. Abstract

Metallized propellant propulsion systems are considered as replacements for the solid rocket boosters and liquid sustainer stages on the current launch vehicles: both the Space Transportation System (STS) and the Titan IV. Liquid Rocket Boosters for the STS were analyzed as replacements for the current Solid Rocket Boosters. These boosters can provide a liquid propulsion system within the volume constraints of a Solid Rocket Booster. A replacement for the Space Shuttle Main Engines using metallized $\mathrm{O}_{2} / \mathrm{H}_{2} / \mathrm{Al}$ was studied. The liquid stages of the Titan IV were also investigated; the A-50 fuel was replaced with metallized storable A-50/Al. A metallized propellant is similar to a traditional liquid propellant. However, it has metal particles, such as aluminum, that are suspended in a gelled fuel, such as hydrogen, RP-1, Aerozine-50 (A-50) or monomethyl hydrazine (MMH). The fuels then undergo combustion with liquid oxygen or nitrogen tetroxide (NTO). These propellants provide options for increasing the performance of existing launch vehicle chemical propulsion systems by increasing fuel density or specific impulse ( $\left.\mathrm{I}_{\mathrm{sp}}\right)$, or both. These increases in density and $\mathrm{I}_{\mathrm{sp}}$ can significantly reduce the propulsion system liftoff weight and allow a liquid rocket booster to fit into the same volume as an existing solid rocket booster. Also, because gelled fuels are akin to liquid propellants, metallized systems can provide enhanced controllability over solid propulsion systems. Gelling of the propellant also reduces the sensitivity to impacts and consequently reduces the propellant explosion hazard.

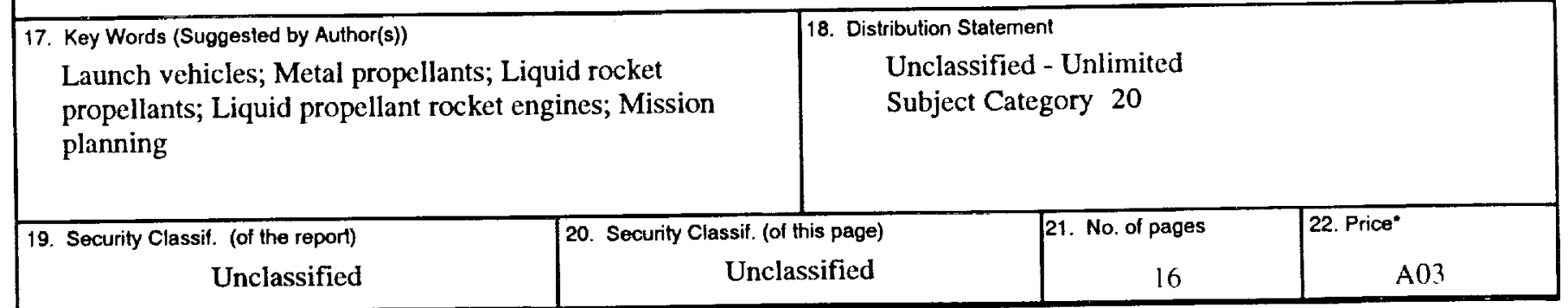


$\vdots$ 